\title{
O JOGO DA AMARELINHA: ENSAIO EM FORMA DE ROMANCE
}

\author{
Lucas Bandeira de Melo Carvalho \\ lucband@gmail.com
}

\section{ROMANCE E ENSAIO}

"Sou eu mesmo a matéria deste livro", escreveu Montaigne (s/d, p. 74) no "Do autor ao leitor" que inicia seus Ensaios. Nesta frase talvez esteja a melhor síntese do que é o ensaio enquanto gênero. Podemos explicar assim a frase de Montaigne: ensaio é aquele texto que parte da experiência pessoal para gerar o pensamento conceitual. Partir do pessoal significa, entre outras coisas, que no ensaio há muito de criação e exercício de liberdade, o que o torna um gênero pouco "científico", pouco atrelado ao método - e, portanto, radicalmente diferente do tratado, da monografia, tangenciando tipos de texto "artísticos".

Esta definição é útil, precisa, e mostra a beleza do ensaio. Mas existe, atrás dessa definição, uma grande indefinição, que hoje, quando tudo é ensaio e todos ensaístas, deve ser encarada. Quando, como agora, chamar um texto de ensaístico se tornou um julgamento (positivo) de valor, falta talvez pensar por que ele é tão valorizado. Se ele é valorizado exatamente por suas indistinções, em que casos a indistinção chega à raiz do gênero e é mais fértil?

Uma das principais indistinções que encontramos no ensaio é entre teoria e literatura, o que pode gerar outras definições para o gênero além das que já demos. (Neste trabalho, me permito usar diversas definições para "ensaio", já que "o ensaio não apenas negligencia a certeza 
indubitável, como também renuncia ao ideal dessa certeza" [ADORNO, 2003, p. 30] ${ }^{1}$.) Ensaio, podemos dizer, é o texto teórico que pode ser lido como literatura. $\mathrm{Ou}$, em outras palavras, o ensaio é aquele texto teórico em que a forma é tão importante quanto o conteúdo e, logo, pode ser válido mesmo quando o conteúdo não é válido.

Por outro lado - e é essa indistinção de que pretendo falar neste... ensaio -, podemos inverter a equação: quando o texto francamente literário, o conto ou, principalmente, o romance, se torna ensaio, ou adquire caráter ensaístico? Esta questão é importante pelo menos desde que, em 1944, Adorno escreveu, em Minima moralia (2008, p.47), que "num mundo em que há muito os livros não se parecem com livros, só o são aqueles que não são mais". Esta frase, claro, tem uma primeira leitura negativa: os livros deixam de ser "livros", suporte para um discurso, para entrar na lógica da moda e da exploração capitalista, enquanto apenas certa literatura de resistência, mimeografada, pontual, circunstancial, manteria a discrição que está na essência do livro. Mas, pensando dialeticamente, podemos identificar a positividade de um livro que não é mais apenas livro, e que com isso ligue campos diversos da existência e se ligue (ou religue) à experiência humana. Esse livro é o romance quando deixa de ser romance. Tal texto do momento, descompromissado com o que o campo literário espera e por isso muito comprometido com a relação da literatura com a vida, é aquilo que Cortázar quis dizer quando afirmou que gostaria de escrever somente takes, improvisos como no jazz: "O melhor da literatura é sempre take, risco implícito na execução, margem de perigo que constitui o prazer do volante, do amor, com tudo o que acarreta de perda sensível mas ao mesmo tempo com aquele compromisso total que em outro plano dá ao teatro sua inconquistável imperfeição diante do cinema perfeito" (CORTÁZAR, 2009, p. 158). Esses takes, reunidos em um livro, formariam um "romance que não parece romance".

Gosto sempre de voltar às definições de Roland Barthes do que é um romance. Como mostra Adorno, o ensaio busca e rechaça a teoria, a definição conceitual: "Assim como o ensaio renega os dados primordiais, também se recusa a definir seus conceitos” (ADORNO, 2003, p. 28). E

1 Poderia fazer todo este texto parafraseando trechos do ensaio de Adorno, em que o filósofo alemão define o ensaio como "rigoroso em não ser sistemático", como gênero de pensamento em que a exposição é tão importante quanto o exposto, em que se chega ao universal olhando o circunstancial; também define como o texto que coloca sua própria negação e que não chega a uma conclusão definitiva: como a arte, expande sentidos, em vez de reduzi-los. 
entre as grandes (e frutíficas) contradições de Barthes estava a de definir sempre, mas não se aferrar nunca a uma definição, como se a negasse.

Para Barthes, ora o romance é duração, conceito retirado da fenomenologia, ora é "deslizamento" de significados. A ideia de duração, a partir de Henri Bergson, quando aplicada no romance, pode ser explicada desta maneira: o leitor tem a experiência de leitura apenas quando consegue se identificar com os personagens, quando experimenta o tempo da mesma maneira como o personagem experimenta. Em $O$ grau zero da escrita, Barthes identifica na duração um dos aspectos que a literatura sempre destrói e reconstrói: "O que se trata de destruir é a duração, isto é, a ligação inefável da existência (...). Mas o que reconquista o escritor ainda é a duração, pois é impossível desenvolver uma negação no tempo sem elaborar uma arte positiva, uma ordem que deve ser de novo destruída" (BARTHES, 2004, p. 34). Nesta primeira definição de romance, abre-se a possibilidade de ver o ensaio como uma obra literária, pois, se for construído como uma história, como uma narrativa formada de conceitos em vez de ações, o ensaio é lido como um romance. Isto significa que, para ser um ensaio, mais do que do conteúdo, novamente se mostra a importância da forma, dos caminhos de leitura.

A segunda definição - romance como deslizamento de significados - , por sua vez, abre a possibilidade de ler o romance como ensaio. Lembremos mais uma vez de Adorno (2003, p. 43): "Suas [do ensaio] transições repudiam as deduções conclusivas em favor de conexões transversais entre os elementos, conexões que não têm espaço na lógica discursiva" - como o desenvolvimento de uma narrativa, que depende da teia de relações entre os personagens. Ambos os gêneros são, portanto, baseados nas "relações", mais que em essências e termos fixos.

Aqui, pretendo analisar um aspecto de um romance - ou melhor, de trechos deste romance - que, acredito, está entre aqueles que melhor sintetizam esse lugar entre o ensaio e o romance. Muito estudado, $O$ jogo da amarelinha (Rayuela) dá àquele que pela primeira vez penetra em seus labirintos a impressão de que está ali uma máquina capaz de conter tudo que existe, uma máquina que seria capaz de continuar absorvendo certo "devir" eternamente, e que apenas a intervenção demiúrgica de um autor, indignado com uma criação que se mostra infindável, maior que ele, é capaz de deter. Acredito ser possível, sem trocar uma palavra, mais uma vez recorrendo ao artigo de Adorno sobre o ensaio, usar o seguinte período para resumir a principal obra de Julio Cortázar: "Ele não começa com Adão e Eva, mas com aquilo sobre o que deseja falar; diz o que a respeito lhe ocorre e termina onde sente ter chegado ao fim, 
não onde nada mais resta a dizer; ocupa, desse modo, um lugar entre os despropósitos" (ADORNO, 2003, p. 17).

Escrito em 1964, O jogo da amarelinha causou um impacto enorme naquela geração que queria, antes de mais nada, liberdade de existência. E era isso que estava inscrito na forma desse romance. Um livro poderia ser tudo, sem deixar de ser romance, nos provava Cortázar. Ele poderia ser um jogo, e esse jogo poderia conter em si trechos de ensaios, alguns absurdos, ensaios ficcionais, mas cujo sentido só seria possível entrever se pensássemos na relação com a obra como um todo. (Em "De outra máquina celibatária” [CORTÁZAR, 2009, p. 123-37], Cortázar descreve uma máquina criada para ler $O$ jogo da amarelinha, levando ao extremo o romance como jogo.) Mas, mesmo diante de tamanha dispersão e fragmentação, ainda estamos com um romance nas mãos, temos certeza disso. Acompanhamos a vida de personagens, nos envolvemos com eles; alguns momentos são tão emocionantes quanto os melhores momentos da literatura realista, mas dentro de um romance que recusa a solução realista. Mesmo assim cabe a pergunta: em sua reunião, os 155 fragmentos formam um romance ou um ensaio, ou um romance realizado à maneira de ensaio? Construído desta maneira, como poucos livros Rayuela aponta para o leitor a indissolubilidade da ligação entre vida e pensamento.

\section{O ENSAIO DENTRO DE O JOGO DA AMARELINHA}

Uma análise de O jogo da amarelinha dificilmente escapa de começar com uma descrição de sua estrutura primária. Como escreveu Alberto Manguel (2000, p. 91), mesmo quem nunca leu ou lerá o livro sabe de sua estrutura, ${ }^{2}$ e por isso não é necessário nos alongar nesta descrição.

Logo no início, o autor explica a mecânica:

À sua maneira, este livro é muitos livros, mas é, sobretudo, dois livros. O leitor fica convidado a escolher uma das seguintes possibilidades:

O primeiro livro deixa-se ler na forma corrente e termina no capítulo 56, ao término do qual aparecem três vistosas estrelinhas que equivalem à palavra Fim. Assim o leitor prescindirá sem remorsos do que virá depois.

O segundo livro deixa-se ler começando pelo capítulo 73 e continua, depois, de acordo com a ordem indicada no final de cada capítulo... (CORTÁZAR, 2003, p. 5.)

2 Manguel também identifica as fontes de Cortázar: Macedonio Fernández, Jorge Luis Borges e Laurence Sterne. 
Logo em seguida, o autor inclui algumas "pistas", antes de entrarmos na história daquele grupo de amigos que viviam com todas as suas forças os anos 1960 em Paris.

Primeiro, ironicamente, conclui a explicação da estrutura do livro com uma "moral" do romance, "animado pela esperança de ser particularmente útil à juventude e de contribuir para a reforma dos costumes em geral" com o que é "a base daquela moral universal tão adequada à felicidade espiritual e temporal de todos os homens" (CORTÁZAR, 2003, p. 6). Em itálico, Cortázar recorre ao artifício de atribuir o livro a outro autor: uma tradução para o espanhol de um texto de um abade toscano escrito em 1797. Esse anacronismo, além de lembrar um recurso de outro argentino, Jorge Luis Borges (ver El hacedor, por exemplo), é uma referência a toda a história do romance, desde Dom Quixote, que, lembremos, já incluía aquilo que séculos depois chamariam de "metalinguagem" e que recorre ao mesmo recurso da falsa tradução. O segundo livro do Quixote nos apresenta o narrador (na verdade, um dos narradores): "Cuenta Cide Hamete Benengeli en la segunda parte de esta historia” (CERVANTES, 2004, p. 549), e no final o próprio Dom Quixote se refere ao livro que o leitor tem em mãos (desde o nascimento o romance carrega o antirromance):

\footnotetext{
Iten, suplico a los dichos señores mis albaceas que si la biena suerte les trujere a conocer al autor que dicen que compuso uma historia que anda por ahí con el título de Segunda parte de las hazañas de don Quijote de la Mancha, de mi parte le pidan, cuan encarecidamente ser pueda, perdone la ocasión que sin you pensarlo le di de haber escrito tantos e tan grandes disparates como en ella escribe, porque parto de esta vida con escrúpulo de haberle dado motivo para escribirlos. (Ibidem, p. 1103-4.)
}

Outra dica que nos dá Cortázar está na primeira epígrafe, uma referência a um tema caro ao autor: como sair da prisão ao "Grande Costume", de viver sem escolhas (poderíamos dizer: como sair da alienação causada pelo modo de produção, pois o costume é nada mais do que o cotidiano da vida administrada).

Aqui entra o primeiro indício de que este romance não é mais um romance puro, nem um que, à moda dos vanguardistas, queira destruir as fronteiras do gênero. Ele reconhece essas fronteiras tanto quanto aquilo que vai além delas, tributário do surrealismo e do existencialismo. Ele não quer ir além do romance: que ir além da escrita. "Quantas vezes me pergunto se isto não é mais que escrita”, diz o segundo parágrafo do capítulo 73, o primeiro na ordem de leitura proposta, "numa época em que corremos para o engano entre equações infalíveis e máquinas 
de conformismos. Mas perguntar de saberemos encontrar o outro lado do hábito ou se mais vale se deixar levar pela sua alegre cibernética, não será mais uma vez literatura?” (CORTÁZAR, 2003, p. 442). Neste ponto já temos um questão proposta, questão que, claro, não terá uma resposta conclusiva, mas momentos em que pendemos para cada um dos lados, pistas falsas. Ou, melhor dizendo, os demais 154 capítulos são o caminho de uma resposta vinda de um discurso do desejo e do improviso, não um programa ou um método de escapar do hábito, de abandonar o conformismo. Mas, de qualquer forma, aí está a questão principal do livro, colocada em um capítulo "prescindível" que o leitor só lerá se escolher ler o livro por inteiro.

Para complicar ainda mais a confiança que depositamos ao narrador como "teórico" ou "ensaísta”, em alguns capítulos, inclusive no 73, somos apresentados ao pensamento - e aos comentários do narrador a esse pensamento - de um autor que parece reunir todas as características do excêntrico. Como pode o narrador ter em Morelli, o pensador delirante, seu guia para a vida e a arte? Talvez, então, não possamos confiar naquilo que o narrador pensa?

Os pensamentos de Morelli, que às vezes aparecem como um capítulo e em outros trechos são lidos e discutidos pelos personagens, são ensaios ficcionais, parte do mundo criado pelo romance. Não apontam para nenhum fora do romance, como apontam as referências a Kant, a Mondrian ou a Jelly Roll Morton. Morelli, embora seja um personagem que só aparece como autor desses textos, divide a mesma linguagem do narrador. Se existe um espaço para seu pensamento (as morellianas, como o narrador chama), próximo ao delírio, há momentos de intercessão com o delírio do narrador e - suspeitamos - do protagonista.

O pensamento conceitual, portanto, é representado como um elemento do mundo. Assim como existe um personagem fictício que pinta, há outro(s) que pensa(m). Esse pensamento é atribuído a duas vozes (que não se distinguem bem): a de Morelli e a do narradorprotagonista. Quando esse pensamento surge sem comentários, sozinho em um capítulo, ele é transformado em elemento exterior à narrativa, junto com as outras citações que aparecem sozinhas em capítulos: esses pensamentos morellianos têm a função de tirar o leitor da duração, de suspender sua identificação com o personagem e lembrá-lo de que se trata de um livro. Ao mesmo tempo, em seu delírio, é um comentário à teoria: lendo, nos perguntamos até que limite o pensamento humano chega, se é possível criar uma teoria ficcional, etc. Ou seja, ao inventar o discurso de Morelli, Cortázar cria, por um meio ficcional, um comentário sobre o ensaio. Essa dobra no romance (a ficção comenta o ensaio, enquanto ela 
mesma se estrutura como ensaio) faz de $O$ jogo da amarelinha - se não quisermos usar o conceito barthesiano de Texto, que talvez se encaixasse perfeitamente: "a exigência de um objeto novo, obtido por deslizamento ou inversão das categorias anteriores. Esse objeto é o Texto" (BARTHES, 2004, p. 66) - um romance indefinível, a meio caminho para o ensaio.

Basicamente, o jogo de $O$ jogo da amarelinha é repetir a dinâmica imersão-emersão do leitor na narrativa diversas vezes, e em nenhum outro capítulo isto é mais bem realizado que naquele em que é narrada a morte de Rocamadour, bebê de Maga, a personagem feminina que surge como símbolo de uma pureza inculta, contrastando com a culpa ilustrada do protagonista (culpa inclusive de traição da nacionalidade). Mas essas imersões são possíveis apenas se o leitor aceitar imergir novamente após emergir, isso porque, ao sermos retirados forçosamente do discurso do narrador por um capítulo de natureza diversa, é suspensa a identificação com a narrativa. Uma nova suspensão de descrença só pode ocorrer se consciente, mas apenas suspendendo novamente a descrença compreenderemos os discursos muitas vezes prolixos do narrador.

Podemos dizer que só podemos esgotar a estrutura de $O$ jogo da amarelinha se anulamos sua riqueza, mais que na maioria dos romances, justamente por sua ideia de abarcar quaisquer referências, históricas, teóricas, artísticas, cotidianas, e relacioná-las sem dirigir a interpretação. Poderíamos falar do doppelgänger entre Oliveira e Traveler, da nacionalidade, da escrita de Cortázar, mas, como esbocei anteriormente, o que me interessa neste trabalho é como o ensaio se imiscui na narrativa, a ponto de chegar a ser elemento narrativo, e, por outro lado, como alguns trechos da história se transformam em momento de ruptura da argumentação, e tomaremos como exemplo maior a morte de Rocamadour, de que trato a seguir.

\section{A MORTE DE ROCAMADOUR}

“Encontraria Maga?” - assim começa o capítulo numerado como primeiro. Nosso narrador - perseguido pelo fantasma da nacionalidade: "Rien ne vous tue un homme comme d'être obligé de représenter un pays", segundo outra epígrafe do romance, retirada de carta de Jacques Vaché a André Breton - apresenta Maga, estranho personagem que, embora construído para ser um contraponto à racionalidade do protagonista (uma peça do jogo), ganha por isso mesmo contornos de uma realidade incontornável. Maga é o único personagem que é algo (mãe), enquanto os 
demais se nomeiam: escritores, pintores, músicos. Ao deixar de ser mãe, com a morte de Rocamadour, ela se tornará um personagem vazio, o que levará à dissolução do núcleo (sem a segurança da figura materna?) e à criação de um novo ambiente com a volta do protagonista à Argentina. Antes de analisar a cena, no entanto, devemos pensar como ela se insere no romance.

Como delineamos, $O$ jogo da amarelinha parece um livro que se desenvolve apenas pelo prazer do discurso, de "falar de algo", e pela defesa da imaginação, do outsider e da vanguarda. Podemos, no entanto, identificar diversas linhas de topoi, que se cruzam e criam uma primeira estrutura problemática. Um desses conflitos se desenrola entre a utopia de uma "vida artística", mais livre e sincera que o "Grande Costume", que a existência burguesa média, e a realidade histórica. A primeira dolorosa ruptura para quem está acompanhando a vida livre dos amigos em Paris surge logo no capítulo 14, em que o autor, sem abandonar em sua linguagem a liberdade que é o análogo formal da liberdade dos personagens, apresenta, por meio de um acontecimento narrativo, um problema para "tese" que parece desenvolver, de que a realidade agride a utopia. Como se preocupar com a ruptura do cotidiano se existe tortura, se em algum lugar a civilização cessou? A ruptura, a antítese, é uma série de fotos de execuções na China. O narrador, aquele mesmo que não sabemos se devemos levar a sério ou não por sua impureza, após descrever em detalhes as fotos e a maneira como, ao terror das imagens brutais, se seguiu mais um momento de cantoria e bebedeira, explica: "como sempre, tudo convergia de várias dimensões, irreconciliáveis, um grotesco collage, que era preciso montar com vodca e categorias kantianas, esses tranquilizantes contra qualquer coagulação muito brusca de realidade. Ou, como quase sempre, fechar os olhos e voltar para trás, para o mundo, para o confortável mundo de qualquer outra noite, escolhida cuidadosamente entre o barulho aberto" (CORTÁZAR, 2003, p. 70-71). À violéncia chinesa, o autor-montador faz suceder (no capítulo 114, que, pela lógica do livro, é o seguinte) uma reportagem sobre execução nos Estados Unidos. Esses dois capítulos, escritos e "editados" desta forma, funcionam como um pedido ao leitor que suspenda sua entrega à história e olhe para aquilo que está fora, como conteúdos fora do quadro, não-diegéticos, que se insinuam apesar da narrativa. E, afinal, no que o leitor pode pensar? Qual é o sentido? Primeiro, que nos dois polos do mundo existe a entrega do Estado à barbárie. Além disso, que a literatura é feita de má consciência, pois aquilo que o narrador faz (ao utilizar metáforas, referências literárias) tem como função esconder a crueldade do mundo. Mas esse "collage" que "era preciso montar com 
vodca e categorias kantianas" é inevitável, e, com má consciência, o narrador volta a se entregar ao jogo literário, para mais à frente nos colocar de novo dentro da realidade histórica - desta vez, no capítulo 15, para a violência contra a mulher, justamente contra a personagem que abre o livro de maneira tão poética e sem violência, Maga. Por fim, no capítulo 16, para complicar ainda mais a equação, Cortázar coloca os personagens a discutir a violência, como em um processo de alienação: como esvaziar o sentido político das fotos de tortura e da violência contra mulheres senão transformá-lo em conteúdo de um discussão que existe apenas em virtude do gosto pela discussão? A substituição da ação pela palavra, ou melhor, pelo jogo - como em grande parte do livro, no capítulo 16 os personagens conversam para testar até onde um diálogo pode ir, para descobrir quem consegue expor melhor a habilidade retórica -, coloca os personagens à margem dos acontecimentos históricos: por mais que eles sejam homens e mulheres como os que sairiam à rua em maio de 68 , de perto, pela luz da narrativa, se mostram apenas espectadores dos acontecimentos políticos.

Mas, afinal, nos perguntamos, de que lado estamos, da realidade, diante da qual deve-se posicionar e agir, ou da liberdade de flutuar nos acontecimentos? (Nós nos fazemos esta pergunta, mesmo já sabendo que nossa resposta será que não é possível escolher. Mas isso não quer dizer que não haja sentido, mas que a obra tem um "caráter de algum modo polissêmico infinito", como disse Barthes [2004, p. 110-1] sobre a liberdade de interpretação dos textos. E, não devemos esquecer, existem diferentes formas de a obra literária não responder a uma pergunta.)

$O$ jogo da amarelinha encontrou um ponto de equilíbrio: não temos como escolher entre a liberdade e o engajamento, já que os dois são inevitáveis, mas irreconciliáveis. Ficamos com o impossível e com a ruptura que isso gera. Somos homens rompidos.

Aproveitando que estamos falando de como o ensaio se imiscui no romance, devemos pensar se, diante daquilo que Adorno escreveu sobre ensaio, não estamos diante do equivalente a "romance de tese", mas em que, em vez de provar uma hipótese, houvesse apenas a interligação consciente de diferentes problemas e conceitos, sem nunca chegar a uma conclusão definitiva. Não se trata apenas de um romance ensaístico, que aborda um tema teórico e utiliza a narrativa tradicional para explorá-lo, mas de um "romance de ensaio", em que a narrativa se desenvolve na forma de ensaio, com rupturas, saltos, indecisões - com as escolhas que apenas aquele que vive pode fazer.

Finalmente chegamos ao capítulo 28, um dos mais longos do livro, que narra a morte de Rocamadour, filho de Maga, e depois como os 
amigos evitam lhe contar o ocorrido, conversando sobre filosofia, até que ela descubra por si própria. Podemos estruturar os momentos deste capítulo segundo um esquema de alternância dos sentidos de realidade e de irrealidade. Primeiro, tudo é realidade, ou choque, que é uma categoria da realidade em seu extremo: Oliveira volta para casa e encontra Maga com Gregorios, que a corteja, e logo nota a morte do bebê. Esta situação - o homem chega em casa e encontra a mulher amada com seu rival e um bebê morto - poderia se encaixar em um romance realista psicológico. Logo, no entanto, partimos no segundo momento para outro registo, especulativo: o conceito. Diante da inevitabilidade do real, da morte, os amigos discutem exatamente sobre o que é o real. Em vez de discutirem sobre algo que é real (a morte), discutem sobre o que é a realidade, como se isso aniquilasse a realidade desse algo. A concretude da morte se torna apenas um exemplo a ser abordado pelo pensamento.

Quando finalmente Maga toma consciência da morte do filho, Ronald, um dos amigos, diz que, em vez de agir, ficou "todo mundo falando besteira". Neste terceiro momento da cena, parece haver uma hipótese: imaginação e pensamento são álibis para não viver. A balança volta a pesar para o lado do real. Há, todavia, mais um passo, o quarto. A discussão entre os amigos era sobre a existência de realidades - o choque, por exemplo, poderia ser a realidade para um deles, enquanto para outro apenas uma iluminação à Rembrandt seria real - e sobre o absurdo, que poderia ser ilustrado pela cena que líamos: existe maior absurdez que amigos aguardando que uma mãe descobrisse que seu filho morrera? Portanto, realidade, discussão, confirmação da realidade, a realidade como absurdo, que por sua vez leva à discussão e a sua negação, parecem configurar uma estrutura modular. Cada elemento tem valor literário em si - realismo psicológico na morte de um bebê, metaliteratura na encenação de um diálogo sobre a realidade, literatura do absurdo, etc. —, e eles dialogam e se contradizem, mas sem se eliminarem. E essa contradição não leva a um niilismo: chega-se perto de uma solução com um desesperado "il faut tenter de vivre", um engajamento existencialista. Mas nem essa fórmula (inevitável) é corroborada pelo narrador.

Nisto, claro, existe algum comentário sobre o poder jovem de maio de 68: o romance é um apoio ao engajamento na realidade, no momento — às causas, ao jazz, à literatura —, mediado pela complexidade que é estar no mundo. Como um ensaio, o livro não é uma representação total do mundo, mas um posicionamento no mundo a partir de fragmentos, e daí os movimentos de contração e expansão da linguagem, com capítulos longos e curtos, filosóficos e realistas, em primeira ou terceira pessoa, felizes ou melancólicos. 


\section{TUDO É ENSAIO, NADA É ENSAIO}

Em Além do bem e do mal, o "eu" aparece para Nietzsche de duas principais maneiras. Primeiro, no fragmento 19, combatendo a unicidade cartesiana ("penso, logo existo") e schopenhaueriana do eu ("quero, logo existo"), afirma que o eu é formado por uma pluralidade de sentimentos e desejos, e o que se afirma como "eu" não seria mais do que aquele conjunto de desejos e sentimentos que dominam e subjugam os demais. "Nosso corpo", nos diz, "é apenas uma estrutura social de muitas almas" (NIETZSCHE, 2006, p. 24). Podemos ainda acrescentar que esse domínio é localizado no tempo, já que, ainda para o filósofo, a unicidade do sujeito só se dá por causa da memória e, mais ainda, do esquecimento. Não há uma unidade em si desse sujeito. A cada momento somos outro.

Esse "eu", no entanto, é para Nietzsche o único lugar a partir do qual o pensamento se desenvolve. Diz ele: "Gradualmente foi se revelando para mim o que toda grande filosofia foi até o momento: a confissão pessoal de seu autor" (Ibidem, p. 12). Em toda frase deve se subentender um "para mim". Melhor dizendo, haveria em todo pensamento um "para mim, neste momento".

Montaigne foi um dos primeiros pensadores a questionar o primado do "eu", e seu dito ("Sou eu mesmo a matéria deste livro") pode ser combinado com o nietzscheano (tudo é "para mim") para chegar a uma síntese lógica: se tudo é "para mim" e o ensaio é aquele texto cuja matéria sou eu, então tudo é ensaio?

Essa pergunta, claro, tem um caráter de caricatura. Como já vimos, o ensaio é uma forma. Se falamos de experiência e de "eu" é porque toda forma traz consigo uma rede de significados, entre eles certa concepção do que é conceito, do que é sujeito, de qual é a função do pensador.

São muitos os textos literários que apresentam características de ensaio. Desde Memórias póstumas de Brás Cubas, de Machado de Assis, aos contos de Jorge Luis Borges. No primeiro caso, são textos que incluem o autoquestionamento, o que certamente é uma caracerística ensaística. No segundo, há uma indefinição de gênero, uma vez que muitos contos têm um caráter mais teórico do que estético (ou, de certa forma, literário).

Como, no entanto, se mostra esse "eu" nesses romances-ensaio? Como se dá esse "para mim", isto é, como a experiência se inscreve na enunciação? Para restringir mais nosso campo de análise, demos perguntar: de que maneira o "para mim" ou a ideia de que "sou eu a matéria deste livro" se insere estruturalmente no texto literário?

Claro, sabemos que no romance existem, segundo a análise do 
discurso, pelo menos três sujeitos em um enunciado: o sujeito do enunciado, que é a voz do personagem; o sujeito da enunciação, que é a voz do narrador; e o autor, que é, segundo Foucault, um papel em relação ao discurso e permite uma função classificatória. No caso da literatura, o autor é aquele artista cujo nome aparece na capa, mas também um conjunto de valores relativos a escolas literárias, reputação e poder.

Mas, quando pensamos no eu problemático da perspectiva do qual o ensaio é escrito, cabe pensar em que lugar da enunciação ele se econtra, e como isso se relaciona com um "romance de ensaio" como $O$ jogo da amarelinha.

Primeiramente, o texto não-ficcional, qualquer que seja ele, também apresenta um sujeito da enunciação, espécie de entidade conjurada pelas escolhas léxicas, gramaticais, etc. Quando o teórico escreve um ensaio, ele está escolhendo para si uma certa voz, com tudo aquilo que ela carrega por causa de seu lugar no campo discursivo. Embora surjam diversos sujeitos dos enunciados - diversas pessoas falam em um ensaio, por meio de citações, paráfrafes, etc. —, os dois outros lugares costumam se identificar (não coindicir): o sujeito da enunciação se identifica com o autor. Se esse sujeito da enunciação é problemático em um ensaio (um "pensador irresuluto"), como isso se dá em um romance de ensaio, em que o sujeito da enunciação não se identifica com o autor, mesmo que haja elementos contextuais que nos levem a imaginar que existam pontos de intercessão entre os dois?

A questão de $O$ jogo da amarelinha passa a ser, então, quem é o narrador. Esse narrador, primeiramente, é fragmentado, e assume as seguintes vozes:

a) a voz de Horacio Oliveira, protagonista;

b) a voz de um narrador onisciente, que narra em terceira pessoa, mas cuja visão de mundo é similar à do protagonista;

c) a voz poética, quando lemos fragmentos que parecem obras literárias à parte;

d) a voz do romance, da montagem, ou da estrutura, quando lemos algum recorte de uma reportagem ou outro material que exista fora do romance.

Existe, no entanto, uma voz dominante, que é a do romance, e o que essa voz faz é estabelecer relações entre os outros narradores. Essa voz é a do eu problemático, é a voz do ensaísta.

No capítulo 8o, um dos narradores fala desse eu problematico. $\mathrm{O}$ capítulo começa com a voz poética e depois assume a voz do protagonista: 
Quando acabo de cortar as unhas ou lavar a cabeça, ou simplesmente agora que, enquanto escrevo, ouço um borbulhar no meu estômago,

tenho a sensação de que meu corpo ficou para trás de mim (não reincido em dualismos, mas faço uma distinção entre mim e as minhas unhas)

e que o corpo começa a ir mal, que nos falta ou nos sobra (depende).

De outro modo: mereceríamos já uma máquina melhor. A psicanálise demonstra como a contemplação do corpo cria complexos prematuros. (E Sartre, que no fato de a mulher ser "esburacada" vê implicações que comprometem toda a sua vida.) Até dói pensar que estamos adiante deste corpo, mas que a dianteira já é um erro e um estorvo e uma provável inutilidade, porque estas unhas, este umbigo,

quero dizer outra coisa, quase inacessível; que a "alma" (o meu eu-nãounhas) é a alma de um corpo que não existe. A alma talvez tenha empurrado o homem para além da sua evolução corporal, mas está cansada de empurrar e, agora, segue sozinha para a frente. Dá apenas dois passos.

e a alma se quebra, ai, porque o seu verdadeiro corpo não existe e a deixa cair, plaf.

A infeliz volta para casa, etc., mas isto não é o que eu. Enfim.

Longo papo com Traveler sobre a loucura. Falando dos sonhos, demonos conta (...) (CORTÁZAR, 2003, p. 459).

Apenas nas últimas frases ficamos sabendo que o texto era escrito (ou pensado) por Oliveira. Poderia ser um dos muitos textos que não possuem nenhuma marca que posicione o narrador e que chamamos de voz poética. Mas aqui temos um problema. As características apontam para um texto escrito (como o uso de quebras de frase e parágrafos iniciando em maiúscula, que demonstram uma "intenção"), embora em momento algum haja indicação de que o narrador do livro - o responsável pela voz que narra em terceira pessoa - é o protagonista. Podemos dizer que aqui também a alma andou mais rápido que o corpo (a palavra), e a linguagem, com suas regras de voz narrativa, simplesmente não resiste. Chega ao ponto em que o eu não mais é sujeito de verbo algum ("mas isto não é o que eu", ponto final).

Caso o lêssemos fora do romance, este fragmento - que poderia estar em $A$ volta ao dia em 8 o mundos ou ser intitulado, talvez, "Lucas e suas unhas”, para figurar em Um tal Lucas - seria um pequeno ensaiocrônica sobre a problemática do eu. Partindo do concreto - do cotidiano cortar as unhas -, chega-se a uma reflexão sobre a relação entre o real (o corpo) e o eu. Em outro momento, em Um tal Lucas (2008, p.11-3), Cortázar usará a metáfora da "hidra" com diversas cabeças para falar da divisão do eu.

O sujeito da enunciação problemático é o sujeito do ensaio porque ele tem diversas cabeças, olha para diversos lados, e não pode concluir, pois, por mais que corte algumas cabeças, sempre nascem outras, como 
a hidra cortazariana. Ou como no "Choro do poeta atual" de Murilo Mendes:

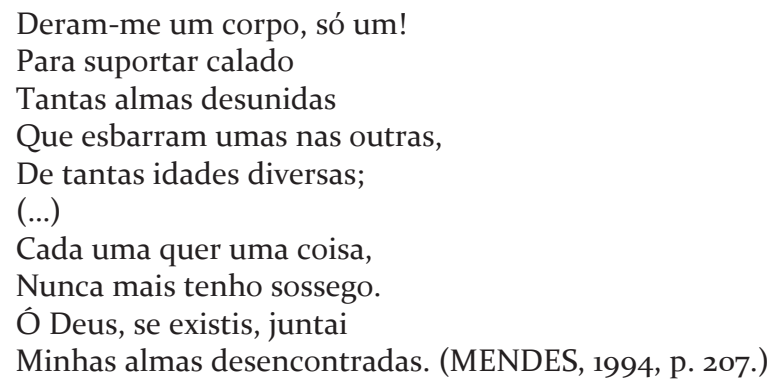

O eu do ensaio, por mais que queira, nunca reunirá suas almas desencontradas, e por isso seu único tema é ele próprio. A cada assunto de que trata, a cada relação que desenha, decepa uma cabeça e brotam tantas outras. Por isso, se existe um filtro discursivo que faz de $O$ jogo $d a$ amarelinha um romance, enquanto, por exemplo, as Notas de literatura de Adorno são ensaios, sob esse filtro se encontra a mesma impossibilidade de unificar uma conclusão, como se, mais que deslizamento de sentidos, o caráter desse texto fosse de colisão de sentidos.

Em $O$ jogo da amarelinha o caráter ensaístico se relaciona com um engajamento existencialista da forma, o que faz com que as concepções do que é o conceito (representado pelas discussões filosóficas), de sujeito (o doppelganger, as vozes do narrador) e da função do pensador (o "engajamento livre", de que falamos) condizem com as do ensaio como forma de pensamento não-dogmático.

\section{O LEITOR DECIDE}

Abrir um romance dizendo que o livro é vários livros significa uma defesa, ou mesmo uma exortação à liberdade da leitura. Mas, claro, existem marcas textuais. O leitor não está perdido no nada: há o texto. Qualquer teoria da leitura demonstra que há limites de interpretação - encontramos isto tanto em Wolfgang Iser quanto em Umberto Eco, que sintetiza com simplicidade a questão: "É possível inferir dos textos coisas que eles não dizem explicitamente - e a colaboração do leitor se baseia nesse princípio -, mas não se pode fazê-los dizer o contrário do que disseram" (ECO, 2004, p. 98).

Como isso se dá em formas abertas? Antes deve-se descobrir quão abertas são. Por mais que não seja conclusivo, o ensaio, nos diz Adorno, 
é sempre enfático: "trabalha enfaticamente na forma de exposição. A consciência da não-identidade entre o modo de exposição e a coisa impõe à exposição um esforço sem limites” (ADORNO, 2003. p. 37).

Também o "romance de ensaio" não tem meias palavras. O choque é profundo, o posicionamento político é claro, a angústia não é abrandada. Mesmo que um livro seja desdobrável em tantos livros quantos forem seus leitores, serão tais livros, não quaisquer livros.

O jogo da amarelinha, portanto, à nossa maneira, é muitos livros, mas sobretudo dois livros. O primeiro livro é a expressão em forma de romance - daremos uma terceira definição do romance: é qualquer conjunto que obtenha sua unidade por meio de um fio condutor narrativo, por isto $O$ jogo é um romance, e não são $A$ volta ao mundo em 80 dias e Último Round - de uma luta contra a alienação do homem moderno. Este livro, tanto em sua forma, que faz o leitor "trabalhar", quanto em seu conteúdo, tem como função despertar o leitor do "costume" - para usar um termo totalmente estranho ao universo de Cortázar, é uma luta contra a "doxa”. É um texto destruidor da cultura, que desconforta, como o "texto de fruição" de que fala Roland Barthes (2002, p. 20-1).

O segundo livro aborda um certo números de questões - de alguma maneira contingentes, ligadas ao ambiente dos anos 1960 - e as relaciona, utilizando para isso de um número de personagens e de uma colagem de materiais da mais diversa procedência, o que o autor, com menos pretensão mas mais radicalidade, faria em $A$ volta ao dia em 1967 e em Último Round em 1969. Esse movimento em direção a conceitos pertence a um modelo de romance que pertenceu a boa parte da história da literatura: o "romance de tese". No entanto, o que faz $O$ jogo da amarelinha é explodir esses conceitos, chocando-os.

Esse romance dividido em dois supõe um certo leitor, que, mais do que se identificar com o universo social e psicológico dos personagens, se identifique com a forma e sua destruição. Um leitor que deseje ultrapassar o sentido do texto e encontrar, ao final do texto, apenas a liberdade de se entregar ao jogo e ao risco que são o que realmente a arte - pelo menos certa arte - tenta, apostando todas as fichas, copiar da vida.

\section{REFERÊNCIAS BIBLIOGRÁFICAS}

ADORNO. Theodor W. "O ensaio como forma”. In: Notas de literatura I. São Paulo: Duas Cidades/Ed. 34, 2003. . Minima moralia. Rio de Janeiro: Azougue, 2008. 
BARTHES, Roland. O prazer do texto. São Paulo: Perspectiva, 2002.

. "A escrita do romance”. In: O grau zero da escrita. São Paulo: Martins Fontes, 2004 .

. "Uma problemática do sentido”. In: Inéditos vol. 1 - teoria. São Paulo: Martins Fontes, 2004.

. “Da obra ao texto”. In: O rumor da língua. São Paulo: Martins Fontes, 2004.

CERVANTES, Miguel de. "Segunda parte del ingenioso cavallero Don Quijote de La Mancha”. In: Don Quijote de La Mancha. São Paulo: Alfaguara, 2004.

CORTÁZAR, Julio. O jogo da amarelinha. 8. ed. Rio de Janeiro: Civilização Brasileira, 2003.

. "Lucas, sus luchas com la hidra". In: Un tal Lucas. Buenos Aires: Punto de Lectura, 2008.

. "De outra máquina celibatária”. In: A volta ao dia em 80 mundos, tomo I. Rio de Janeiro: Civilização Brasileira, 2009.

. "Melancolia das malas". In: A volta ao dia em 80 mundos, tomo II. Rio de Janeiro: Civilização Brasileira, 2009.

ECO, Umberto. Seis passeios pelos bosques da ficção. São Paulo: Cia. das Letras, 2004.

MANGUEL, Alberto. “A imaginação no poder! Lembrando Julio Cortázar”. In: No bosque do espelho. São Paulo: Cia. das Letras, 2000.

MENDES, Murilo. "Choro do poeta atual”. In: Poesia completa e prosa. Rio de Janeiro: Nova Aguilar, 1994.

MONTAIGNE. Ensaios. Rio de Janeiro: Ediouro, s/d.

NIETZSCHE, Friedrich. Além do bem e do mal. São Paulo: Cia. de Bolso, 2006. 